\title{
Penectomy for self-neglected opportunistic carcinoma: a large primary urogenital squamous cell carcinoma as initial manifestation of HIV-AIDS
}

\author{
Antonio Jose Reyes, ${ }^{1}$ Kanterpersad Ramcharan, ${ }^{2,3}$ Lester Goetz, ${ }^{4,5}$ Samuel Aboh ${ }^{1}$
}

${ }^{1}$ Infectious Disease Unit/ Medicine, San Fernando Teaching Hospital, San Fernando, Trinidad and Tobago ${ }^{2}$ Department of Medicine, San Fernando Teaching Hospital, San Fernando, Trinidad and Tobago

${ }^{3}$ Department of Medicine, Surgi-Med Clinic, San

Fernando, Trinidad and Tobago ${ }^{4}$ Department of Urology, University of the West Indies, St Augustine, Trinidad and Tobago

${ }^{5}$ Department of Urology, Gulf View Medical Centre, San Fernando, Trinidad and Tobago

\section{Correspondence to} Dr Kanterpersad Ramcharan, kramcharan79@yahoo.com

Accepted 1 August 2016

\section{DESCRIPTION}

A previously well, uncircumcised 54-year-old man presented to the emergency department with a large primary tumour of the penis (figure 1). The mass had been growing for 2 years and medical attention was not sought previously.

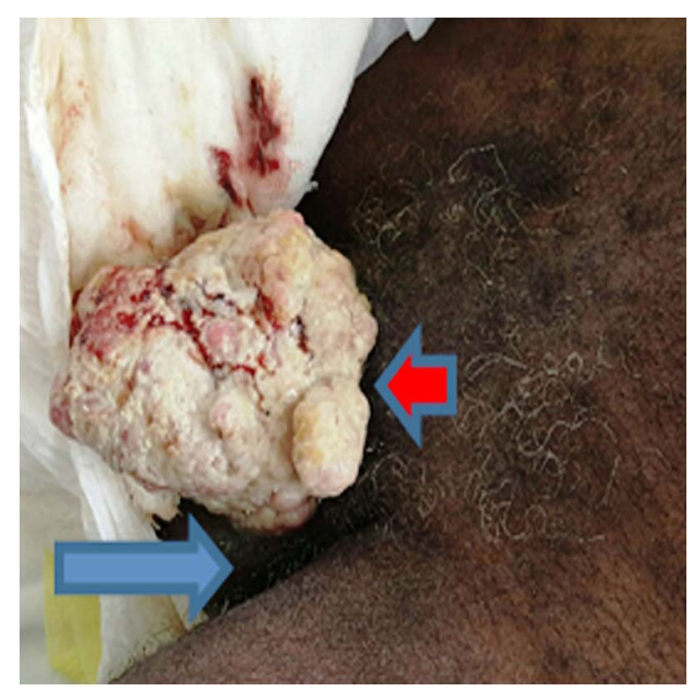

Figure 1 Photograph of the penis of $13.5 \mathrm{~cm}$ in length largely replaced by an extremely malodorous deforming fungating cauliflower-like solid whitish-yellow mass with a size of $12.0 \times 6.6 \times 8.0 \mathrm{~cm}$ (red arrow). Scrotum appears uninvolved (blue arrow).
On examination the patient was bedridden due to generalised wasting syndrome characterised by a body mass index of $18 \mathrm{~kg} / \mathrm{m}^{2}$ and generalised muscle atrophy. Poor intake of food and oral candidiasis were noted. Genital examination showed the penis of $13.5 \mathrm{~cm}$ in length largely replaced by an extremely malodorous, deforming, fungating, cauliflower-like, solid, whitish-yellow mass with a size of $12.0 \times 6.6 \times 8.0 \mathrm{~cm}$. Palpable, multiple, bilateral, fixed, non-tender inguinal lymph nodes (largest $1.5 \mathrm{~cm}$ ) were noted. The scrotum was uninvolved. The rest of physical examination was normal.

Urinary flow was normal but there was dysuria and nocturia. The haemoglobin value was $7.3 \mathrm{~g} / \mathrm{dL}$ (reference values 14.0-17.5) and mean corpuscular volume was $73.2 \mathrm{fL} /$ red cell (reference values 80 96). Western blot immunoassay test and HIV rapid test by ELISA were positive confirming the diagnosis of newly onset HIV-AIDS. Venereal Disease Research Laboratory test was non-reactive. Urine culture grew Citrobacter freundii complex and Klebsiella pneumoniae both sensitive to tigecycline. Extensive investigations for autoimmune, metastatic and other infectious diseases were negative. On admission, the HIV viral load was 200312 RNA copies/mL (reference values 20-10000 000) and the CD4+ T-cell count was 5 cells $/ \mu \mathrm{L}$ (reference values 410-1590). Three months later, the HIV viral load dropped to 28312 RNA copies/mL and the CD $4+\mathrm{T}$-cell count was 150 cells $/ \mu \mathrm{L}$. The prostate-specific antigen was normal. Identification
A

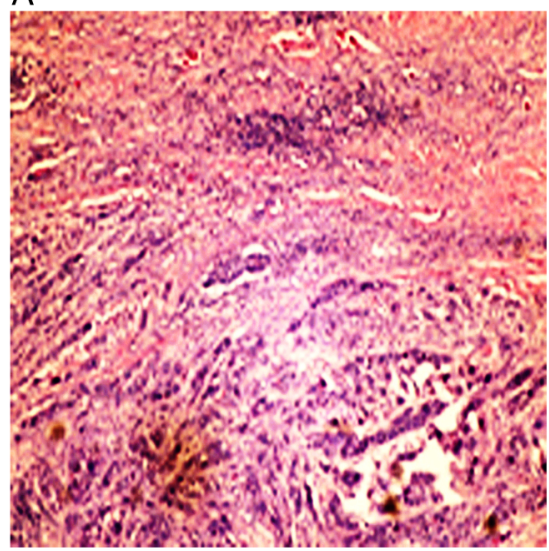

B

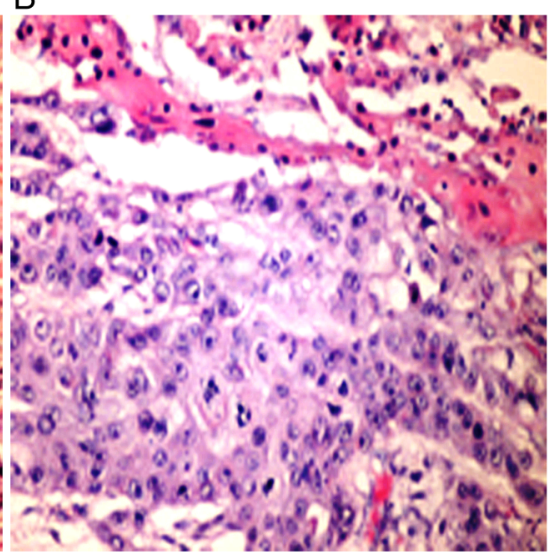

To cite: Reyes AJ, Ramcharan K, Goetz L, et al. BMJ Case Rep Published online: [please include Day Month Year] doi:10.1136/ bcr-2016-217040
Figure 2 Penis tumour photomicrography with routine H\&E staining: (A) magnification $\times 10$ showing a finger-like projection of atypical squamous cells, which often appear as concentrically arranged nests of cells surrounding keratin pearls pattern typical of well-differentiated squamous cell carcinoma grade I (Broders classification); and (B) magnification $\times 40$ showing the epithelial cells with intact desmosomes and atypia, with enlarged and pleomorphic nuclei and one or more prominent nucleoli. 
of human papillomavirus (HPV) DNA by the use of molecular hybridisation techniques was unavailable. CT scan of the chest, abdomen and pelvis showed multiple lymphoid nodes of $1.7 \mathrm{~cm}$ in size located in the inguinal region bilaterally.

Total penectomy with perineal urethrostomy was performed and tumour histopathology using routine $\mathrm{H} \& \mathrm{E}$ staining showed features consistent with well-differentiated squamous cell carcinoma (SCC) with invasion of the corpus cavernosum and corpus spongiosum. Lymphovascular permeation was not seen and the urethra was not involved. Proximal resection margin was free of tumour (figure 2A, B). Fine-needle aspiration cytology of the inguinal lymph nodes suggested reactive hyperplasia. Our patient was classified as penile SCC Jackson stage II and

\section{Learning points}

- A large squamous cell carcinoma (SCC) of the penis requiring total amputation of the genital organ is rare as initial manifestation of HIV-AIDS.

- Primary SCC is the most common malignant neoplasms of the penis.

- The differential diagnosis for penile SCC includes erythroplasia of Queyrat, metastatic carcinoma of the skin, verruciform xanthoma, verrucous carcinoma and genital warts.

- The diagnoses of penile tumours may be delayed because many patients tend to disregard early asymptomatic lesions and often seek medical attention at an advanced stage when a conservative surgical approach is no longer feasible.

- On the basis of the stage, the treatment of the SCC of the penis may include radiation therapy, medical therapy, and surgery, alone or in combination.
T2N0M0 stage II which has a 5-year survival rate of 55\%. ${ }^{1}$ The patient improved postoperatively and after antibiotic treatment with highly active antiretroviral therapy (HAART) and tigecycline $100 \mathrm{mg}$ intravenous infusion initially followed by $50 \mathrm{mg}$ intravenous infusion two times a day for 7 days. Three months later, he remains on oral emtricitabine $(200 \mathrm{mg})$-tenofovir disoproxil fumarate $(300 \mathrm{mg}$ ) and efavirenz $600 \mathrm{mg}$ once daily.

The oncogenic properties of HPV types 16, 18, 31 and 33 may be involved in the developments of primary SCC of the penis. HPV prevalence in penile cancers is high at about $40 \%$, being HPV16 the predominant genotype accounting for $\sim 63 \%$ of HPV-positive tumours among patients with HIV-AIDS. HPV vaccination has a positive role in preventing SCC of the penis and anus among patients with HIV-AIDS. ${ }^{23}$

\begin{abstract}
Acknowledgements The authors thank Ms Sharon Sealey for preparing the photographs. They acknowledge Dr Wayne Mohammed for interpreting the pathological specimens and preparing the photomicrographs. They also thank the patient for allowing them to write this case as a case report for teaching and medical education purposes.
\end{abstract}

Contributors AJR conceived the idea of the report and drafted the manuscript. LG performed the surgery. All the authors contributed to the intellectual content of the final manuscript and are responsible for the contents. All the authors assume responsibility for the final contents.

Competing interests None declared.

Patient consent Obtained.

Provenance and peer review Not commissioned; externally peer reviewed.

\section{REFERENCES}

1 Horenblas S, van Tinteren H. Squamous cell carcinoma of the penis. IV. Prognostic factors of survival: analysis of tumor, nodes and metastasis classification system. J Urol 1994;151:1239-43.

2 Sasco AJ, Jaquet A, Boidin E, et al. The challenge of AIDS-related malignancies in sub-Saharan Africa. PLOS ONE 2010;5:e8621.

3 Purtilo DT. Opportunistic cancers in patients with immunodeficiency syndromes. Arch Pathol Lab Med 1987;111:1123-9.

Copyright 2016 BMJ Publishing Group. All rights reserved. For permission to reuse any of this content visit

http://group.bmj.com/group/rights-licensing/permissions.

BMJ Case Report Fellows may re-use this article for personal use and teaching without any further permission.

Become a Fellow of BMJ Case Reports today and you can:

- Submit as many cases as you like

- Enjoy fast sympathetic peer review and rapid publication of accepted articles

- Access all the published articles

- Re-use any of the published material for personal use and teaching without further permission

For information on Institutional Fellowships contact consortiasales@bmjgroup.com

Visit casereports.bmj.com for more articles like this and to become a Fellow 